Article

\title{
Influence of Changes in Botanical Diversity and Quality of Wet Grasslands through Phenological Phases on Cow Milk Fatty Acid Composition
}

\author{
Radisav Dubljević $^{1}$, Božidarka Marković ${ }^{1}$, Dušica Radonjić ${ }^{1, *}$, Danijela Stešević ${ }^{2}$ \\ and Milan Marković ${ }^{1}$ \\ 1 Biotechnical Faculty, University of Montenegro, Mihaila Lalica 1, 81000 Podgorica, Montenegro; \\ ratod@ac.me (R.D.); bmarkovic@t-com.me (B.M.); mmarkoni@t-com.me (M.M.) \\ 2 Faculty of Science and Mathematics, University of Montenegro, Džordza Vasingtona bb, \\ 81000 Podgorica, Montenegro; danijela.denist@gmail.com \\ * Correspondence: dusicar@ucg.ac.me
}

Received: 9 June 2020; Accepted: 3 August 2020; Published: 6 August 2020 updates

\begin{abstract}
Natural pastures in Montenegro, together with natural meadows, are the most important forage source and comprise $95 \%$ of the used agricultural area (UAA). The aim of this study was to estimate the changes in grassland biomass, chemical and floristic composition and fatty acid composition in milk of cows grazed on Agrostis stolonifera semi-natural wet grassland in the Central region of Montenegro. Investigation was conducted during three phenological phases: early vegetative, optimal vegetative and full reproductive phase. The chemical composition of the grassland biomass was changed through the phenological phases. A significant increase during the experimental period in the content of dry matter and crude fibers and a decrease in crude protein content were determined. The pasture community consisted of 52 species, belonging to 19 families. The total amount of plant species classified as excellent, very good and good quality was $7.69 \%$, while medium quality plants amounted to $13.46 \%$, low quality plants to $19.23 \%$, valueless plants to $34.62 \%$ and toxic plants to $25 \%$. The total quality index was 4.166 . The highest quality index of this community was in the second phenological phase, then in the third phase the lowest quality was in the first phenological phase. According to the floristic composition and biomass quality, this lowland pasture can be qualified as being of moderate to good quality. The content of milk fat, protein and solid non-fat (SNF) was increased from the first to the third vegetation phase, but the differences between the phases were not significant $(p>0.05)$. The content of a majority of saturated fatty acids (SFAs) also increased, while the total content of monounsaturated fatty acids (MUFAs) was high in the second phase and decreased significantly in the third phase. The content of polyunsaturated fatty acids (PUFAs) was constant in the first two phases, while it significantly decreased in the third phase. The highest content of most of MUFAs and PUFAs was obtained in the second phenological phase. The content of fatty acids in the third phase significantly affected $(p<0.05)$ by the phenological phase. This research contributes to the improvements in the grazing management of wet grasslands as well as the animal performances (milk yield and quality of milk).
\end{abstract}

Keywords: grassland; botanical diversity; phenological phase; fatty acids; milk

\section{Introduction}

Extensively managed grasslands are widely recognized today for their high biodiversity and their multiple ecosystem services (ES) [1]. Wet grasslands can be considered as transitional wetland ecosystems of floodplains which include the species-rich cropped grasslands and grazed pastures and 
species-poorer grazing areas of the lowlands [2]. This type of grassland is endangered by conversion to improved grasslands or abandonment due to the difficulties associated with exploiting land that is not suitable for use. Despite the widespread distribution of wetland areas, feeding values of forage from wet grasslands have been poorly studied [3]. There is a positive correlation between the ecological type of grassland and floristic composition, meaning that drier grasslands have a more favorable floristic composition [4].

Natural grasslands and pastures constitute an extremely high part of the agricultural land of Montenegro, reaching $94.2 \%$ of total area [5]. Montenegro is botanically one of the most interesting parts of Southeastern Europe; about 3600 plant species and subspecies grow there [6], of which slightly more than $10 \%$ have the status of being endemic to the Balkan Peninsula [7]. The biodiversity of grasslands, especially biodiversity of wet grasslands, has not been sufficiently studied in Southeast Europe [8], including Montenegro where the wet grasslands are mostly located in the Central region, in the area of Podgorica and Danilovgrad municipalities. The pastures in this area have been used extensively for years, and no agrotechnical measures have been applied to improve them. Milk production in Montenegro and the rearing of ruminants is mostly based on the use of natural grasslands and pastures [9]. Grazing plays the most important role in the nutrition of dairy cows in many regions of the world [10]. The use of grazing in feeding of dairy cows has several advantages, such as increasing the opportunities to encourage the natural behavior of cows and contributing to the image of the dairy sector, but it also has deficiencies, such as greater nitrate excretion and less balanced nutrition [11,12].

The monitoring of pasture quality through the evaluation of protein and fiber content over time is critical to define the nutritional value of pastures and design balanced diets for grazing animals [13]. Pasture biomass is one of the most complete and cheapest feeds. The content of lipids in the feed is influenced by a large number of factors, of which the participation of leaves in plants is one of the most important. According to the results of Stainwidder et al. [14], pasture samples showed a high content of net energy and protein, significantly more than silage and hay.

It is well documented that diet, management regime, and the extent of biohydrogenation in the rumen are critical to determine the fatty acid (FA) composition in the milk of dairy cows [15]. Researching the distinguishing factors of nutritional milk quality is a key to sustainable production and addresses the increasing media and scientific scrutiny regarding the human health effects and ecological impacts of dairy products [16].

The milk composition and yield are affected by many factors. Grazing has a beneficial effect on the fatty acid profile of milk and milk products, resulting in an increased concentration of useful fatty acids such as omega 3 FA, conjugated linoleic acid and vaccenic acid and reduced palmitic acid and omega 6 FA [17].

Differences in the milk fatty acids' profile depending on the botanical composition are partly explained by limiting polyunsaturated fatty acid (PUFA) biohydrogenation in the rumen by plant secondary metabolites from different grasslands. The above explanations apply only to the effect of botanical diversity. In fact, many other factors such as animal characteristics and physical activity, pasture management, and the plant phenological phase may also affect the fatty acid profile of milk [18].

The concentration of fatty acids in grass biomass varies through phenological phases, with the highest value of total fatty acids being present in the spring, decreased levels in July and increased levels at the end of the season [19]. Understanding the effects of changes in grassland botanical composition and the timing of grazing on the nutritional composition of pasture could help in improving grazing management during summer and, consequently, animal performance and the quality of milk [20].

The aim of this study was to investigate the influence of changes in the botanical diversity and quality of wet grasslands biomass on changes in the milk composition and fatty acid profile during different vegetation phases. 


\section{Materials and Methods}

\subsection{Field Research}

The investigation was performed in a wet grassland area of an Agrostis stolonifera community situated in the Central region of Montenegro $\left(42^{\circ} 28^{\prime} 46.3^{\prime \prime} \mathrm{N}, 19^{\circ} 11^{\prime} 0.28^{\prime \prime} \mathrm{E}\right.$, at $40 \mathrm{~m}$ above sea level) from April to the middle of July 2017. This grassland belongs to the group of moist grasslands, but not boggy grasslands which are used only for grazing. Alluvial and brown soils with a high degree of influence from nearby groundwater are represented in this area [21]. This area is characterized by a Mediterranean climate with hot summers and average daily temperature from April to September of $24.7^{\circ} \mathrm{C}$ (with an average minimal temperature of $12.6^{\circ} \mathrm{C}$ and maximum temperature of $30.8^{\circ} \mathrm{C}$ ), along with an average precipitation of $41.7 \mathrm{~mm}$ [22]. A typical dairy farm from this region with 12 milking cows mostly crossbreds of Holstein Frisian and local breeds were selected for the investigation. All cows were multiparous and were in about of the middle stage of lactation. The farming system was semi-extensive or extensive, based only on grazing during vegetation, while during winter time, feeding was mostly by hay from natural grasslands with a small addition of concentrate feeds. The experiment was organized in three phases, according to the phenological phases of grass: early vegetative phase, late or optimal vegetative phase and reproductive phase. The interval between phenological phases was 45 days. Favorable climate condition in the investigated area affected the early start of grass vegetation. The first sampling of grassland biomass, assessment of botanical composition and milk sampling was performed in the beginning of April. The next sampling was at the second phenological phase at the end of May, and the third sampling in the full reproductive phase of vegetation was in early July. Milk samples for the analysis of chemical and fatty acids composition were collected and the daily milk yield recorded (morning and evening milking) from all selected cows in three phenological phases.

\subsection{Botanical Assessment}

The assessment of the botanical structure and composition of plant communities was done using the standard Braun-Blanquet methodology [23]. The releves (description and classification of botanical composition) of the investigated grassland were taken inside three plots, with a size of $10 \times 10 \mathrm{~m}^{2}$, in three different vegetation phases: the early vegetation phase, the second or optimal vegetation phase and third full reproductive phase. The herbarium material collected in each phenological phase is deposited in the herbarium collection. The identification of plant species was performed by using standard keys for plant identification, while the nomenclature followed Euro+Med [24]. The quality of grassland was determined as the proportional share of certain functional groups. Modified quality indices for individual plant species were used, since the descriptive grade of quality [25] was translated into numerical values and modified according to Peeters and Dajić Stevanović [26]. The value of the quality index of plant species can be in the range from -2 to 12 , where a value from -2 to 0 indicates toxic plants, 1 to 2 valueless plant species, 3 to 4 species of low quality, 5 to 6 medium quality species, 7 to 8 species of good quality, 9 to 10 species of very good quality and a value of 11 to 12 indicates excellent quality species.

\subsection{Grassland Biomass Chemical Composition Analysis}

The grass samples for analyzing chemical composition were collected according to the procedure AS1064 [27], and the analyzes were performed according to AOAC [28]. The moisture content was analyzed by the gravimetric method; crude protein content based on total $\mathrm{N}$ content by the Kjeldahl method (multiplying $\mathrm{N}$ content by the factor 6.25 ). The total cellulose content was analyzed according to the manufacturer's procedure of the Gerhart Fibertherm fiber extraction device and in accordance to the Henneberg Stohman method; the total fat content determined according to the manufacturer's procedure of the SOXTHERM fat extraction device (Gerhardt, Germany) using Soxhlet method. The total ash content was determined by the gravimetric method after burning the grass samples at $540-600{ }^{\circ} \mathrm{C}$. 


\subsection{Milk Chemical Composition Analysis}

Two milk samples $(2 \times 50 \mathrm{~mL})$ from each of 12 cows in three vegetation phases were taken according ICAR roles for milk recording [29]. The samples were placed in hand refrigerators and transported from the farm to the laboratory. One milk sample was used for chemical analyses and the other for the analysis of fatty acids composition.

The chemical analysis (fat, protein, lactose and solid non-fat content) was performed by instrumental methods using the MilkoScan 4000 instrument in the Dairy Laboratory of the Biotechnical Faculty. MilkoScan operates on the principle of infrared spectrophotometry [30].

\subsection{Determination of Milk Fatty Acids (FA)}

Milk samples for analysis of FA composition, after being transported from the farm, were immediately stored in a freezer at a temperature of $-40{ }^{\circ} \mathrm{C}$ and kept until analysis. The FA methyl esters were detected using a Gas Chromatograph-Mass Spectrophotometry (GCMS-QP2010 Plus; Shimadzu, Kyoto, Japan) according to ISO Standard 15,885 [31] in the Laboratory for Ecotoxicological research. The system was equipped with mass selective detector with an ion source having a temperature of $220^{\circ} \mathrm{C}$ and interface temperature of $260^{\circ} \mathrm{C}$. For the detection of fatty acids, SP-2560 fused silica capillary column of $100 \mathrm{~m}, 0.25 \mathrm{~mm}$ ID and $0.20 \mu \mathrm{m}$ film thickness was used. The results are expressed as a percentage of the FA methyl ester in the total FA content. The content of saturated and unsaturated fatty acids (C 4:0 to C 24:1) was determined.

\subsection{Statistical Analysis}

Data analysis of the grassland chemical composition, milk chemical composition and fatty acids composition of cow milk in three vegetation phases was done using one-way ANOVA. The significance of differences between the obtained average values in the three vegetation phases was determined using Fisher's Least Significant Difference (LSD) test. The significant differences were compared at the level $p<0.05$. The analysis was performed in the StatSoft Statistica software, version 10 [32].

\section{Results}

\subsection{Floristic Composition}

The plant communities of the studied wet grassland consisted of 52 species, belonging to 19 families. Grasses (fam. Poaceae) accounted for $21.21 \%$ of the total, daisies (fam. Asteraceae) for $15.38 \%$, legumes (fam. Fabaceae) for $9.61 \%$, sedges (fam. Cyperaceae) for $13.46 \%$ and rushes and mints (Juncaceae and Lamiaceae) accounted for 5.76 of the total. The results of floristic composition and the structure of the plant communities in different vegetative phases are given in Table 1.

Group of characteristic species of the plant community consisted of: Agrostis stolonifera L., Gratiola officinalis L., Anthoxanthum odoratum L., Lotus tenuis Willd. and Ononis spinosa L. (Table 1). Absolute frequency in all phases, but lower cover values were shown by carices (Carex caryophyllea Latourr., C. distans L., C. filiformis L., C. flacca Schreb., C. spicata Huds.), Cynosurus cristatus L., Potentilla reptans L., Plantago lanceolata L., Cichorium intybus L. and Taraxacum officinale Weber. The floristic composition and structure varied considerably through the vegetative phases. The first phase was characterized by the flowering of carices and grasses (Alopecurus rendlei, Anthoxanthum odoratum and Cynosurus cristatus) as well as the vegetative development of Agrostis stolonifera, Gratiola officinalis, Lotus tenuis, etc. In total, the first phase exhibited 37 species, while in the second and third phase, 46 and 41 species were reported. In the second vegetative stage carices had already reached the end of their flowering season, while Gratiola officinalis, Lotus tenius, Agrostis stolonifera, Bromus recomosus L., Oenanthe silaifolia M. Bieb., etc., were in full bloom. The third stage of vegetation was characterized by the appearance of Prunella lanciniata (L.) L., Pulicaria dysenterica (L.) Bernh, and Mentha pulegium L. and disappearance of Alopecurus rendlei, Bromus racemosus L., Oenanthe silaifolia M. Bieb., Galium palustre L., 
Luzula multiflora (Ehrh.) Lej. Due to the high domination of Agrostis stolonifera L. in all phenological phases, this wet grassland is classified as an Agrostis stolonifera community.

Table 1. Floristic composition (FC) and plant community structure in different phases.

\begin{tabular}{|c|c|c|c|c|c|c|c|c|c|}
\hline \multirow{2}{*}{ Species } & \multicolumn{3}{|c|}{ FC 1-April } & \multicolumn{3}{|c|}{ FC 2-May } & \multicolumn{3}{|c|}{ FC 3-July } \\
\hline & $I^{*}$ & II * & III * & $I^{*}$ & II * & III * & $I^{*}$ & II * & III * \\
\hline Agrostis stolonifera L. & 3 & 3 & 3 & 3 & 3 & 4 & 3 & 3 & 4 \\
\hline Gratiola officinalis L. & 3 & 2 & 2 & 3 & 2 & 2 & 3 & 2 & 2 \\
\hline Anthoxantum odoratum L. & 1 & 1 & 2 & 2 & 2 & 2 & 3 & 2 & 2 \\
\hline Lotus tenuis Willd. & 1 & 2 & 1 & 1 & 2 & 1 & 1 & 1 & 1 \\
\hline Ononis spinosa L. & + & 1 & 1 & + & 2 & 1 & + & 2 & 1 \\
\hline Carex caryophyllea Latourr. & 1 & 1 & 1 & 1 & 1 & 1 & 1 & 1 & 1 \\
\hline Carex distans $\mathrm{L}$. & 1 & 1 & 1 & 1 & 1 & 1 & 1 & 1 & 1 \\
\hline Carex filiformis L. & 1 & 1 & 1 & 1 & 1 & 1 & 1 & 1 & 1 \\
\hline Carex flacca Schreb. & 1 & 1 & 1 & 1 & 1 & 1 & 1 & 1 & 1 \\
\hline Carex spicata Huds. & 1 & 1 & 1 & 1 & 1 & 1 & 1 & 1 & 1 \\
\hline Cynosurus cristatus L. & 1 & 1 & 1 & 1 & 1 & 1 & 1 & 1 & 1 \\
\hline Potentilla reptans L. & 1 & 1 & 1 & 1 & 1 & 1 & 1 & 1 & 1 \\
\hline Plantago lanceolata $\mathrm{L}$. & 1 & 1 & + & 1 & 1 & + & 1 & 1 & + \\
\hline Cichorium intybus L. & + & 1 & 1 & + & 1 & 1 & + & + & + \\
\hline Taraxacum officinale Weber. & + & 1 & 1 & + & 1 & 1 & + & + & + \\
\hline Alopecurus rendlei Eig & 2 & 1 & + & 1 & + & + & - & - & - \\
\hline Galium palustre L. & 1 & 1 & 1 & 1 & 1 & 1 & - & - & - \\
\hline Oenanthe silaifolia M. Bieb. & + & + & 1 & 1 & 1 & - & - & - & - \\
\hline Juncus compressus Jacq. & + & + & - & 1 & 1 & - & + & + & - \\
\hline Ranunculus marginatus d'Urv. & + & - & - & 1 & + & + & + & - & - \\
\hline Leontodon taraxacoides (Vill.) Mérat. & + & - & - & + & + & - & 1 & 1 & 1 \\
\hline Lythrum salicaria $\mathrm{L}$. & 2 & - & - & 2 & - & - & 1 & - & - \\
\hline Cardamine matthioli Moretti & 1 & - & - & 1 & - & - & + & - & - \\
\hline Scirpoides holoschoenus (L.) Soják & + & - & - & 1 & - & - & 1 & - & - \\
\hline Genista tinctoria $\mathrm{L}$. & - & 2 & 2 & + & 1 & 1 & + & + & + \\
\hline Agrostis castellana Boiss. \& Reut. & - & 1 & 2 & - & 2 & 2 & - & 1 & 1 \\
\hline Lolium perenne L. & - & + & + & - & 1 & 1 & - & + & + \\
\hline Luzula multiflora (Ehrh.) Lej. & - & 1 & 1 & - & 1 & 1 & - & - & - \\
\hline Schedonorus pratensis (Huds.) P. Beauv. & - & - & + & 1 & 1 & 1 & + & 1 & 1 \\
\hline Cynodon dactylon (L.) Pers. & - & - & + & - & 1 & 1 & - & 1 & 1 \\
\hline Centaurea jacea subsp. angustifolia (DC.) Gremli & - & - & - & + & 1 & 1 & 1 & 1 & 1 \\
\hline Cyperus longus L. & - & - & - & 1 & 1 & 1 & 1 & + & + \\
\hline Mentha aquatica L. & - & - & - & 1 & 1 & 1 & + & + & + \\
\hline Trifolium patens Schreb. & - & - & - & + & 1 & 1 & + & + & + \\
\hline Bromus racemosus L. & - & - & - & 1 & 1 & 1 & - & - & - \\
\hline Centaurium erythraea Rafn & - & - & - & - & 1 & + & - & + & + \\
\hline Pulicaria dysenterica (L.) Bernh. & - & - & - & - & - & - & 1 & 1 & - \\
\hline Mentha pulegium L. & - & - & - & - & - & - & - & + & 1 \\
\hline Prunella lanciniata (L.) L. & - & - & - & - & - & - & - & 1 & 1 \\
\hline
\end{tabular}

${ }^{*}$ I, II, III-plots; Braun-Blanquet cover scale: $r,+, 1,2,3,4$. Only species with cover value equal or bigger than 1 are given in the table.

The investigated wet grasslands have been extensively used for years without the application of agrotechnical measures. Due to presence of the grasses Schedonorus pratensis, Phleum nodosum and Lolium perenne, in addition to legumes such as Lotus tenuis and Trifolium patens, these plant communities could be assessed as being of moderate to good quality. Alisma plantago-aquatica, Aristolochia rotunda, Gratiola officinalis and species from the genus Carex and Juncus decrease the quality value of Agrostis stolonifera pasture.

According to the quality index, the best quality of this Agrostis stolonifera community was in the second phase (2.892), then in the third phase (2.865); the worst was in the first phase (2.606). The total quality index of this grassland was 4.166 . The participation of plant groups varied significantly between the vegetative phases (Figure 1). The participation of excellent, very good and good quality plants was significantly increased in the second phenological phase, and slightly in the third. The participation of medium-quality plants was equal in the first and third phase and highest in the second (13.63). 
Low-quality plants showed the highest content in the second phase (25\%). The share of valueless plants decreased in the second, and increased in the third phase. The participation of harmful (toxic) plants was equal in the first and third phase and lowest in the second (25\%).

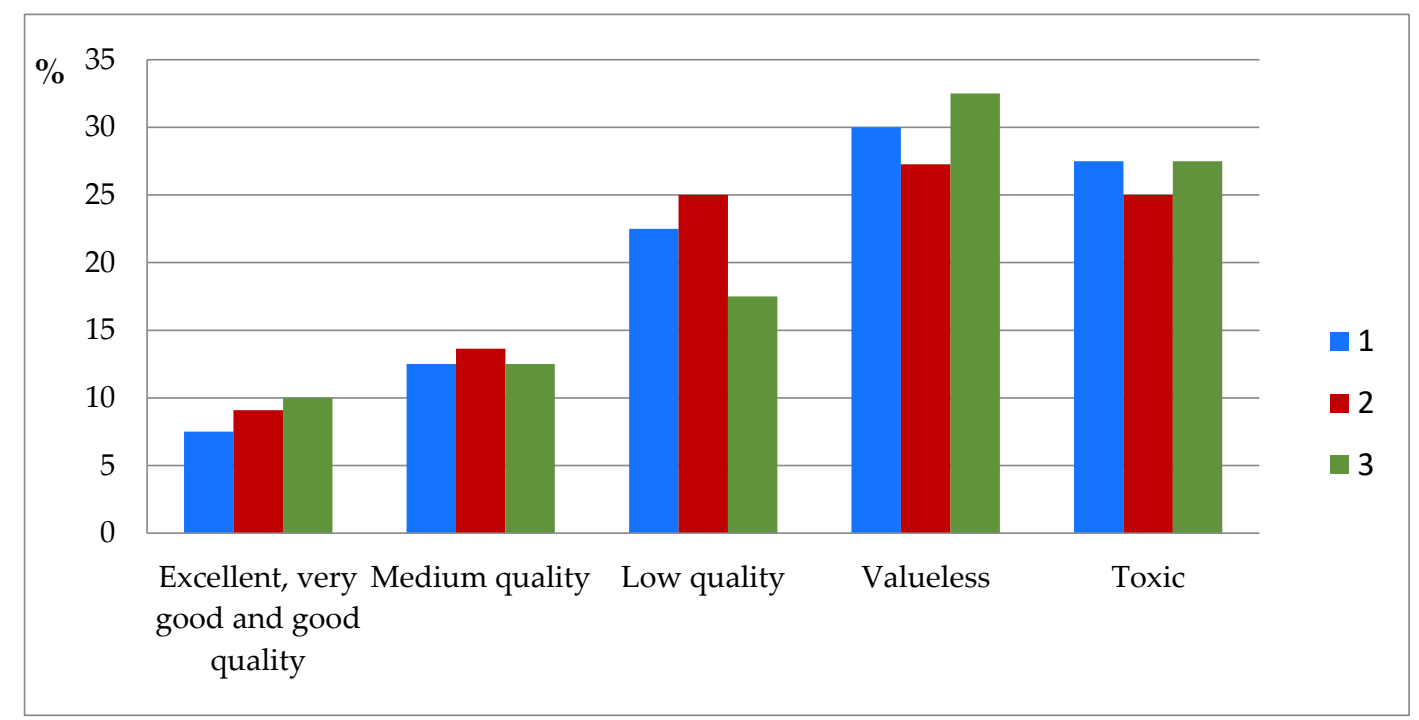

Figure 1. Participation of plant quality groups in three phenological phases. Phenological phases: 1, early vegetative phase; 2 , optimal vegetative phase; 3 , reproductive phase.

\subsection{Chemical Composition of the Grassland Biomass}

The chemical composition of the grassland biomass was also changed in the consecutive phenological phases (Table 2). The dry matter (DM), total crude fibers and total fat content were increased significantly during the research period $(p<0.05)$. The reduced energy intake due to the low DM content was the main limiting factor for high milk production of grazing cows. In contrast to these components, the protein and ash content were decreased in the consecutive phenological phases.

Table 2. Chemical composition of grassland biomass in three phenological phases.

\begin{tabular}{cccccc}
\hline $\begin{array}{c}\text { Phenological } \\
\text { Phases }\end{array}$ & $\begin{array}{c}\text { DM, \% } \\
\text { Mean } \pm \text { SD }\end{array}$ & $\begin{array}{c}\text { CP, \% } \\
\text { Mean } \pm \text { SD }\end{array}$ & $\begin{array}{c}\text { TF, \% } \\
\text { Mean } \pm \text { SD }\end{array}$ & $\begin{array}{c}\text { CF, \% } \\
\text { Mean } \pm \text { SD }\end{array}$ & $\begin{array}{c}\text { Ash, \% } \\
\text { Mean } \pm \text { SD }\end{array}$ \\
\hline 1 & $19.59 \pm 0.48^{\mathrm{a}}$ & $17.42 \pm 0.27^{\mathrm{a}}$ & $1.31 \pm 0.28^{\mathrm{a}}$ & $20.91 \pm 0.61^{\mathrm{a}}$ & $6.92 \pm 0.22^{\mathrm{a}}$ \\
2 & $28.24 \pm 0.53^{\mathrm{b}}$ & $13.36 \pm 0.31^{\mathrm{b}}$ & $1.50 \pm 0.07^{\mathrm{b}}$ & $25.56 \pm 0.37^{\mathrm{b}}$ & $6.89 \pm 0.19^{\mathrm{a}}$ \\
3 & $40.19 \pm 0.55^{\mathrm{c}}$ & $10.37 \pm 0.29^{\mathrm{c}}$ & $1.59 \pm 0.26^{\mathrm{c}}$ & $29.75 \pm 0.58^{\mathrm{c}}$ & $5.48 \pm 0.29^{\mathrm{b}}$ \\
\hline
\end{tabular}

$\mathrm{DM}$, dry matter; $\mathrm{CP}$, crude protein; $\mathrm{TF}$, total fat; $\mathrm{CF}$, crude fibers; $\mathrm{SD}$, standard deviation. The values with different letters in subscript mean significant differences between mean values in same column $(p<0.05)$ on the base LSD test $(\mathrm{df}=6)$. The values without a letter in subscript mean no significant difference between mean values $(p>0.05)$.

\subsection{Chemical Composition of Milk and Milk Yield}

The mean values and standard deviations for the milk components and daily milk yield (DMY) are presented in Table 3. The fat content was the lowest in the second phase (3.67\%) and highest in the third, reproductive, phase of vegetation (3.87), but without significant differences between each phase $(p>0.05)$. The protein content varied slightly between phenological phases (from $3.09 \%$ to $3.20 \%)$. The content of lactose was very constant $(4.50 \%-4.46 \%)$. Non-fat solids (proteins, lactose and a small portion of the minerals) varied in a narrow range $(8.34 \%-8.40 \%)$, without the influence of phenological phase. The level of standard deviation indicate high variation in all milk components in the first phases of vegetation, while the lowest variation in milk composition was found in the third-reproductive phases, which also confirms that the best quality and composition of biomass was found in this vegetative stage. The average daily milk yield (DMY) in the whole experiment was $17.04 \mathrm{~kg} /$ day. Different in milk composition, DMY was very variable through phonological phases. 
The highest was in the second or optimal vegetative phase $(19.18 \mathrm{~kg} / \mathrm{day})$, while the lowest was in the third phase $(15.90 \mathrm{~kg})$ with a significant difference between phenological phases $(p<0.05)$.

Table 3. Milk chemical compositions and DMY grouped in three phenological phases.

\begin{tabular}{cccccc}
\hline $\begin{array}{c}\text { Phenologal } \\
\text { Phases }\end{array}$ & Fat, \% & Protein, \% & Lactose, \% & SNF, \% & DMY, kg \\
\cline { 2 - 6 } & Mean \pm SD & Mean \pm SD & Mean \pm SD & Mean \pm SD & Mean \pm SD \\
\hline 1 & $3.71 \pm 0.58$ & $3.10 \pm 0.27$ & $4.51 \pm 0.26$ & $8.34 \pm 0.39$ & $16.14 \pm 1.52^{\mathrm{a}}$ \\
2 & $3.67 \pm 0.39$ & $3.17 \pm 0.18$ & $4.51 \pm 0.24$ & $8.40 \pm 0.31$ & $19.18 \pm 1.59^{\mathrm{b}}$ \\
3 & $3.86 \pm 0.35$ & $3.20 \pm 0.14$ & $4.46 \pm 0.19$ & $8.40 \pm 0.28$ & $15.90 \pm 2.73^{\mathrm{a}}$ \\
\hline
\end{tabular}

SNF, solid non-fat; DMY, daily milk yield; SD, standard deviation. The mean values with different letters in subscript mean significant differences between mean values in same column $(p<0.05)$ on the base LSD test $(\mathrm{df}=28)$.

The values without a letter in subscript mean no significant difference between phenological phases $(p>0.05)$.

\subsection{Fatty Acid Composition}

The total 35 fatty acids were determined in the milk samples, of which 17 were saturated (Table 4). The content of saturated fatty acids (SFAs) was permanently increased from the first (68.63\%) to the third phenological phase ( $90.97 \%$ of total fatty acids). This increase was mostly the result of the increase in short-chain FAs. Fatty acids C4:0 to C16:0 were increased through the phases, except C11:0, which content was decreased between phases. Two fatty acids, C17:0 and C18:0, had the lowest content in the second phase.

Table 4. Milk saturated fatty acid (SFA) content (\% of total fatty acid methyl esters (FAME)).

\begin{tabular}{cccc}
\hline & \multicolumn{3}{c}{ Phenological Phase } \\
\cline { 2 - 4 } Fatty Acids & $\mathbf{1}$ & $\mathbf{2}$ & $\mathbf{3}$ \\
\cline { 2 - 4 } & Mean \pm SD & Mean \pm SD & Mean \pm SD \\
\cline { 2 - 4 } C4:0; butyric & $0.84 \pm 0.13^{\mathrm{ns}}$ & $0.95 \pm 0.16^{\mathrm{ns}}$ & $1.82 \pm 0.47^{*}$ \\
C6:0; caproic & $0.98 \pm 0.09^{\mathrm{ns}}$ & $1.07 \pm 0.18^{\mathrm{ns}}$ & $2.23 \pm 0.35^{*}$ \\
C8:0; caprylic & $0.83 \pm 0.08^{\mathrm{ns}}$ & $0.90 \pm 0.19^{\mathrm{ns}}$ & $1.61 \pm 0.19^{*}$ \\
C10:0; capric & $2.17 \pm 0.28^{\mathrm{ns}}$ & $2.30 \pm 0.53^{\mathrm{ns}}$ & $3.71 \pm 0.42^{*}$ \\
C11:0; undecylic & $0.19 \pm 0.04^{\mathrm{ns}}$ & $0.18 \pm 0.04^{\mathrm{ns}}$ & $0.14 \pm 0.04^{*}$ \\
C12:0; lauric & $2.78 \pm 0.38^{\mathrm{ns}}$ & $2.93 \pm 0.61^{\mathrm{ns}}$ & $4.20 \pm 0.54^{*}$ \\
C13:0; tridecylic & $0.11 \pm 0.03^{\mathrm{ns}}$ & $0.12 \pm 0.04^{\mathrm{ns}}$ & $0.13 \pm 0.03^{*}$ \\
C14:0; myristic & $11.52 \pm 1.42^{\mathrm{ns}}$ & $12.05 \pm 0.78^{\mathrm{ns}}$ & $15.78 \pm 1.20^{*}$ \\
C15:0; pentadecylic & $1.75 \pm 0.21^{\mathrm{ns}}$ & $1.77 \pm 0.12^{\mathrm{ns}}$ & $1.94 \pm 0.33^{*}$ \\
C16:0; palmitic & $31.10 \pm 2.78^{\mathrm{ns}}$ & $32.07 \pm 3.10^{\mathrm{ns}}$ & $41.33 \pm 4.39^{*}$ \\
C17:0; margaric & $1.25 \pm 0.20^{\mathrm{ns}}$ & $1.24 \pm 0.14^{\mathrm{ns}}$ & $1.12 \pm 0.22^{*}$ \\
C18:0, stearic & $15.34 \pm 2.43^{\mathrm{ns}}$ & $14.94 \pm 2.68^{\mathrm{ns}}$ & $16.38 \pm 2.64^{*}$ \\
C20:0; arachidic & $0.35 \pm 0.08^{\mathrm{ns}}$ & $0.30 \pm 0.08^{\mathrm{ns}}$ & $0.27 \pm 0.06^{\mathrm{ns}}$ \\
C21:0; heneicosilic & $0.05 \pm 0.01^{\mathrm{ns}}$ & $0.05 \pm 0.01^{\mathrm{ns}}$ & $0.07 \pm 0.02^{\mathrm{ns}}$ \\
C22:0; behenic & $0.30 \pm 0.06^{\mathrm{ns}}$ & $0.31 \pm 0.05^{\mathrm{ns}}$ & $0.12 \pm 0.02^{*}$ \\
C23:0; tricosylic & $0.17 \pm 0.06^{\mathrm{ns}}$ & $0.18 \pm 0.03^{\mathrm{ns}}$ & $0.07 \pm 0.01^{*}$ \\
C24:0; lignoceric & $0.12 \pm 0.05^{\mathrm{ns}}$ & $0.11 \pm 0.03^{\mathrm{ns}}$ & $0.06 \pm 0.01^{*}$ \\
\hline & $68.63^{2}$ & 71.49 & 90.97 \\
\hline
\end{tabular}

* Significant difference between mean values of three phenological phases $(p<0.05)$; ${ }^{\text {ns }}$, no significant differences between means in the same row $(p>0.05)$. Phenological phases: 1 , early vegetative phase; 2 , optimal vegetative phase; 3 , reproductive phase.

The participation of individual SFAs were very similar in each phases, with the highest amount of C16:0, then C18:0 and C14:0 (11.52\% to 41.33\%); the next three SFAs (C10:0, C12:0 and C15:0) amounted in the range from $1.75 \%$ to $4.20 \%$, while the other SFAs accounted for less than $1 \%$ of the total fatty acid content.

The phenological phase had significant influence on the majority of saturated fatty acids only in the third phase, while for the first two phases there was no significance. 
Phenological phases did not affect the content of C20:0 and C21:0. As SFAs are less desirable in terms of their effects on human health, their content was the most favorable in the first phenological phase. In the second phase, their content was slightly lower, while the worst content was in the third phase.

Nine monounsaturated fatty acids (MUFAs) were determined. Six of them (C15:1, C17:1, C20:1, C22:1n9, C18:1n9t and, C24:1) were determined only in traces, and three of them presented in Table 5. The total content of MUFA was quite uniform in the first two phases, although somewhat lower in the second $(26.81 \%$ and $25.13 \%)$, while in the third phase of vegetation their content significantly decreased $(7.79 \%)$. C18:1n9c had the largest share through all phonological phases with a decreasing trend $(25.02 \%$ to $7.79 \%)$.

Table 5. Milk monounsaturated fatty acid (MUFA) content (\% of total fatty acid methyl esters (FAME).

\begin{tabular}{cccc}
\hline \multirow{2}{*}{ Fatty Acids } & $\mathbf{1}$ & $\mathbf{3}$ & $\mathbf{3}$ \\
\cline { 2 - 4 } & Mean \pm SD & Mean \pm SD & Mean \pm SD \\
\cline { 2 - 4 } & $0.64 \pm 0.21^{\mathrm{ns}}$ & $0.72 \pm 0.26^{\mathrm{ns}}$ & $0.30 \pm 0.09^{*}$ \\
C14:1, cis; myristosleic & $1.15 \pm 0.21^{\mathrm{ns}}$ & $1.16 \pm 0.36^{\mathrm{ns}}$ & $0.48 \pm 0.12^{*}$ \\
C16:1, cis; palmitoleic & $25.02 \pm 2.74^{\mathrm{ns}}$ & $23.25 \pm 1.69^{\mathrm{ns}}$ & $7.01 \pm 1.73^{*}$ \\
C18:1n9c; oleic & $26.81^{3}$ & 25.13 & 7.79 \\
\hline
\end{tabular}

$\mathrm{SD}$, standard deviation. ${ }^{*}$ Significant difference between mean values of phenological phases $(p<0.05)$; ns, no significant differences between means $(p>0.05)$. Phenological phases: 1 , early vegetative phase; 2 , optimal vegetative phase; 3 , reproductive phase.

The content of C14:1 and C16:1 was highest in the second phase, while the content of C18:1n9c decreased through the phases. A significant influence of the phenological phase on all MUFAs was found only in the third phase. As the MUFAs are desirable in terms of their effects on human health, their content was most favorable in the first phenological phase. In the second phase, their content was slightly lower, while the worst content was in the third phase.

The content of nine polyunsaturated fatty acids (PUFAs) was determined (Table 6). The total content of PUFA in the first two vegetative phases was almost the same (3.37\% and $3.38 \%)$, with a similar share of individual fatty acids. C18:2n6c and C18:3n3 exhibited the largest amounts, while the other PUFAs accounted for less than $1 \%$ of the total fatty acids. These two acids are also the most important PUFAs.

Table 6. Milk polyunsaturated fatty acid (PUFA) content (\% of total FAME).

\begin{tabular}{cccc}
\hline \multirow{2}{*}{ Fatty Acids } & \multicolumn{3}{c}{ Phenological Phase } \\
\cline { 2 - 4 } & $\mathbf{1}$ & $\mathbf{2}$ & $\mathbf{3}$ \\
\cline { 2 - 4 } & Mean \pm SD & Mean \pm SD & Mean \pm SD \\
\hline C18:3n3; alpha linolenic & $2.11 \pm 0.24^{\mathrm{ns}}$ & $2.01 \pm 0.28^{\mathrm{ns}}$ & $0.63 \pm 0.14^{*}$ \\
C18:2n6c; linoleic & $1.17 \pm 0.27^{\mathrm{ns}}$ & $1.28 \pm 0.22^{\mathrm{ns}}$ & $0.54 \pm 0.19^{*}$ \\
C20:3n6; dihomo-gamma-linolenic & $0.09 \pm 0.03^{\mathrm{ns}}$ & $0.09 \pm 0.02^{\mathrm{ns}}$ & $0.05 \pm 0.01^{*}$ \\
& $3.37^{*}$ & 3.38 & 1.22
\end{tabular}

$\mathrm{SD}$, standard deviation; * Significant difference between mean values of FA in phenological phases $(p<0.05)$; $\mathrm{ns}$, no significant differences between means $(p>0.05)$. 1, early phenological phase; 2 , optimal phenological phase; 3 , reproductive phase.

The lowest PUFAs content $(1.22 \%)$ was obtained in the third phase. Five polyunsaturated fatty acids were present in traces (C18:3n6, C18:2n6t, C20:2, C20:3n3, C22:2). Alpha linolenic and linoleic fatty acids had the highest content in the second phase. A significant influence of the phenological phase on all PUFAs was obtained in the third phase. 
As PUFAs are most desirable in terms of their effects on human health, their content was highest in the second phenological phase. In the first phase, the total content was slightly lower (3.37\%) than in second (3.38\%), while it was the lowest in the third phenological phase (1.22\%).

\section{Discussion}

Grazing is one of the best uses of wet grassland as it contributes greatly to food and feed production, to botanical diversity and to the preservation of the entire agro ecosystem [33]. The traditional method of cattle feeding uses extensive or semi extensive farming systems based on grazing, especially in geographic areas with high domination of natural grasslands and pastures, as in Montenegro [34].

Botanical records of the floristic composition and structure of wet pastures in Montenegro are rather poor [35-37]. According to the Prodromus of plant communities in Montenegro [38], as well as the studies of Bešić [39] and Hadžiablahović [40], the following plant communities were reported on humid pastures: Peucedano-Molinietum littoralis, Bromus racemosus and Vulpia ligustica comm., Alopecurus rendlei comm. and Agrostis stolonifera comm. All communities are distributed in the southern and sub-Mediterranean part of Montenegro, while the first three are considered to be vegetation equivalents of the Natura 2000 habitat type: 6540 sub-Mediterranean grasslands of the Molinio-Hordeion secalini [41]. Thus, besides agricultural importance, these pastures have significant conservation value. The pasture community examined in this study is named Agrostis stolonifera comm., but due to the lack of phytocoenological relevés or information about the floristic composition of the Agrostis stolonifera comm. reported for the surroundings of Skadar Lake [40], comparison of these communities and calculation of the similarity index was not possible. An Agrostis stolonifera community from the studied area is characterized by a significant presence of sedges and rushes, which are the least digestible species. Sedges and rushes represent one of the main concerns for farmers in wet grasslands [3].

The noticeable decrease in the presence of some species in the third phase (Lythrum salicaria) indicates that the animals like to graze them. In the second phase, Cynodon dactylon is an indicator of pasture trampling.

Our results of grassland biomass chemical composition are in agreement with previous studies of Almeida et al. [42] reported for Portuguese Mediterranean pasture and O'Callaghan et al. [17], where increasing proportions of structural carbohydrates (cellulose, hemicelluloses and lignin) with plant growth were also obtained, while protein content decreased. The similar content of dry matter and protein in pasture biomass was reported by Duignan et al. and Botana et al. [43,44].

In correlation with the maturing of the grassland biomass, the chemical composition of milk is changed and the content of milk fat in it is increased, as well as the content of saturated fatty acids. This was especially expressed in the third phenological phase, where the greatest change in the chemical composition of biomass occurred. High temperatures in the later stages also reduce the digestibility of biomass, affecting milk composition.

The chemical composition of cow's milk is in line with the results of Akert at al. and Veiga et al. [45,46]. On the other hand, the research of O'Callaghan et al. [17] and Gulati et al. [47] reported higher content of fat $(4.65 \%)$ and protein $(3.65 \%)$ in the milk of cows fed on pasture. Changes in milk fat and protein content are affected by changes in the floristic and chemical composition of biomass. This research found a positive influence of grazing time on the content of protein and fat in milk, which is very important regarding keeping animals on pastures during the entire grazing period. These facts justify the maximum use of grazing. However, milk yield and fatty acid composition still underline the need to improve cow's nutrition, especially in the late stages when the quality of the pasture is decreased. Milk yield is a very variable trait that is affected by a very large number of factors. Milk yield on a test day, in addition to the chemical composition of milk, can be a good indicator of the animal's reaction to the amount of pasture biomass, as well as its composition and quality. The milk yield in this study was in line with numerous studies [34,48]. The milk yield was increased in the second phase, in which the floristic and chemical composition of biomass was the most favorable. The decline in the third phase was caused by the deterioration of biomass quality. 
The total amount of SFAs found was in line with the results of Shingfield et al. [48], who reported about $70 \%$ SFA in cow milk. The concentration of fatty acids in grass mass varied throughout the phenological phases, with the highest value of total fatty acids in spring, decreased levels in July and increased levels at the end of the season [19]. Veiga et al. [46] determined the content of saturated acid in the milk of grazing cows on natural pastures, similar to the results of this study. These results were consistent with numerous studies confirming that the botanical composition of pastures is influenced by the phenological phase of plants [18,49].

The level of MUFAs in grasses changed slightly with grass maturation [50]. Similar results regarding MUFA contents were reported in [48,51]. Higher MUFA and PUFA content in cow's milk on wet pasture were reported in [52].

In most studies, PUFA content was decreased after the early stage of vegetation. In this research, the PUFA content was the highest in the second phenological phase due to favorable floristic and chemical composition of the grassland in the second phase, and still-high share of green leaves in the grass mass, even in the third phase. Furthermore, the weather conditions were favorable (sufficient precipitation, no drought), which contributed to the preservation of sufficient biomass.

Similar to our results, a significant influence of the phenological phase on the content of PUFA in the milk of grazing cows was reported by Coppa et al. [53]. The decrease in C18:3n 3 with grassland maturation found in this experiment is consistent with Revello-Chion et al., Glasser et al. and Coppa et al. [53-55]. The slightly higher PUFA content in cow's milk fat compared to PUFA content in this study was also obtained by $\mathrm{O}^{\prime}$ Callaghan et al. [17]. A similar content of PUFA was found by Stergiadis et al. [51], while Veiga et al. [46] found a higher PUFA content in the milk of grazing cows compared to the PUFA content obtained in this research.

Differences in the fatty acid milk profile depending on the botanical composition were confirmed in many studies and were partially explained by the limiting of PUFA biohydrogenation in the rumen by plant secondary metabolites from a diverse grasslands. These explanations refer only to the effect of floristic diversity. In fact, some uncontrolled factors such as animal characteristics and physical activity, pasture management, and the phenological phase may also affect the milk fatty acid profile [18].

Sustainable use of wet grasslands along with adjustment of timing of grazing can be an effective strategy for managing botanical composition and optimizing the quality of the herbage offered to ruminants throughout a grazing season [20]. Early exploitation by grazing in the first two vegetative phases would generally lead to higher energy values and better animal performances.

\section{Conclusions}

The results of this study indicate a significant influence of the phenological phase on the chemical and floristic composition of the grassland biomass, as well as on the chemical composition of milk, its quantity and fatty acid composition. Most of the indicators showed the highest values in the second and first phenological phase, while in the third phase a significant decrease was observed in the quality and composition of biomass, as well as in the quantity and composition of cow's milk. Bearing in mind the importance of pastures in the ruminant diet in Montenegro and their participation in the used agricultural area (UAA), this research contributes to improvement in the grazing management of wet grasslands, especially regarding the timing of grazing, improvement in animal performances and better understanding of the value and ecosystem services provided by this type of grassland. Hence, further investigations of this subject are needed and they should involve a larger set of wet grasslands and the other types of pastures in Montenegro.

Author Contributions: Conceptualization, D.R., R.D. and B.M.; methodology, D.S.; software, M.M.; validation, M.M., B.M. and R.D.; formal analysis, B.M.; investigation, D.R.; resources, R.D.; data curation, D.S.; writing-original draft preparation, D.R.; writing—review and editing, R.D.; visualization, D.R.; supervision, B.M.; project administration, M.M.; funding acquisition, M.M. All authors have read and agreed to the published version of the manuscript.

Funding: This research received no external funding. 
Conflicts of Interest: The authors declare no conflict of interest.

\section{References}

1. Bengtsson, J.; Bullock, J.M.; Egoh, B.; Everson, C.; O'Connor, T.; O’Farrell, P.J.; Smith, H.G.; Lindborg, R.; Everson, T. Grasslands-More Important for Ecosystem Services than You Might Think. Ecosphere 2019, 10, e02582. [CrossRef]

2. Joyce, C.; Simpson, M.; Casanova, M. Future Wet Grasslands: Ecological Implications of Climate Change. Ecosyst. Heal. Sustain. 2016, 2, e01240. [CrossRef]

3. Tasset, E.; Boulanger, T.; Diquelou, S.; Laîné, P.; Lemauviel-Lavenant, S. Plant Trait to Fodder Quality Relationships at both Species and Community Levels in Wet Grasslands. Ecol. Indic. 2019, 97, 389-397. [CrossRef]

4. Alibegović-Grbić, S.; Erić, P.; Vučković, S.; Ćupina, B.; Dubljević, R.; Ivanovski, P.; Prentović, T.; Gatarić, Đ.; Nedović, B. Unapređenje Proizvodnje Krme na Prirodnim Travnjacima; Univerzitet u Sarajevu, Poljoprivredni fakultet: Sarajevu, Bosnia and Herzegovina, 2005.

5. Monstat; Stocni fond. Statistical Office of Montenegro; Monstat: Podgorica, Montenegro, 2019.

6. Stesević, D.; Caković, D. Katalog Vaskularne Flore Crne Gore; CANU: Podgorica, Montenegro, 2013 ; Volume I.

7. Vuksanović, S.; Tomović, G.; Niketić, M.; Stevanović, V. Balkan Endemic Vascular Plants of Montenegro-Critical Inventory with Chorological and Life-Form Analyses. Willdenowia 2016, 46, 387-397. [CrossRef]

8. Dengler, J.; Janišová, M.; Török, P.; Wellstein, C. Biodiversity of Palaearctic Grasslands: A Synthesis. Agric. Ecosyst. Environ. 2014, 182, 1-14. [CrossRef]

9. Wilkinson, J.M.; Lee, M.R.F.; Rivero, M.J.; Chamberlain, A.T. Some challenges and opportunities for grazing dairy cows on temperate pastures. Grass Forage Sci. 2019, 75, 1-17. [CrossRef]

10. Marković, M.; Marković, B.; Dubljević, R.; Radonjić, D.; Đokić, M.; Jovović, Z.; Mirecki, N. Poljoprivreda Planinskih Područja, Priručnik za Proizvođače; Univerzitet Crne Gore, Biotehnički fakultet: Podgorica, Montenegro, 2017.

11. Hennessy, D.; Delaby, L.; van den Pol-van Dasselaar, A.; Shalloo, L. Increasing Grazing in Dairy Cow Milk Production Systems in Europe. Sustainability 2020, 12, 2443. [CrossRef]

12. Elgersma, A. Effects of Grassland and Grazing Management on Fatty Acid Intake and Milk-A Review. Grassl. Sci. Eur. 2016, 21, 128-131.

13. Demanet, R.; Mora, M.L.; Herrera, M.A.; Miranda, H.; Joseacute, M.B. Seasonal Variation of the Productivity and Quality of Permanent Pastures in Adisols of Temperate Regions. J. Soil Sci. Plant Nutr. 2015, 15, 111-128. [CrossRef]

14. Steinwidder, A.; Starz, W.; Podstatzky, L.; Kirner, L.; Pötsch, E.M.; Pfister, R.; Gallnböck, M. Changing towards a Seasonal Low-Input Pastoral Dairy Production System in Mountainous Regions of Austria-Results from Pilot Farms during Reorganization. EGF 2010 Kiel Ger. Grassl. Sci. Eur. 2010, 15, 1012-1014.

15. Mangwe, M.; Bryant, R.; Gregorini, P. Rumen Fermentation and Fatty Acid Composition of Milk of Mid Lactating Dairy Cows Grazing Chicory and Ryegrass. Animals 2020, 10, 169. [CrossRef]

16. Davis, H.; Chatzidimitriou, E.; Leifert, C.; Butler, G. Evidence That Forage-Fed Cows Can Enhance Milk Quality. Sustainability 2020, 12, 3688. [CrossRef]

17. O'Callaghan, T.F.; Hennessy, D.; McAuliffe, S.; Sheehan, D.; Kilcawley, K.; Dillon, P.; Ross, R.P.; Stanton, C. The Effect of Cow Feeding System on the Composition and Quality of Milk and Dairy Products. Grassl. Sci. Eur. 2018, 23, 751-754.

18. Coppa, M.; Cabiddu, A.; Elsässer, M.; Hulin, S.; Lind, V.; Martin, B.; Mosquera-Losada, M.R.; Peeters, A.; Prache, S.; Van den Pol-van Dasselaar, A.; et al. Grassland-Based Products: Quality and Authentication. Grassl. Sci. Eur. 2017, 22, 39-60.

19. Dalmannsdóttir, S.; Kristjansdottir, T.H.A. Fatty Acids Concentrations in Forage Species during Growing Season in Iceland. Grassl. Sci. Eur. 2018, 23, 142-146.

20. Gorlier, A.; Lonati, M.; Renna, M.; Lussiana, C.; Lombardi, G.; Battaglini, L.M. Changes in Pasture and Cow Milk Compositions during a Summer Transhumance in the Western Italian Alps. J. Appl. Botany Food Qual. 2012, 85, 216-223. 
21. Fuštić, B.; Đuretić, G. Soils of Montenegro; University of Montenegro, Biotechnical faculty: Podgorica, Montenegro, 2000; pp. 115-122.

22. Institute for Hydrometeorology and Seizmology of Montenegro-Annual Report; Institute for Hydrometeorology and seizmology of Montenegro: Podgorica, Montenegro, 2019.

23. Braun-Blanquet, J. Pflanzensoziologie: Grundzuge der Vegetationskunde, 3rd ed.; Springer: Wien, Austria, 1964.

24. Euro + Med. Euro + Med PlantBase-The Information Resource for Euro-Mediterranean Plant Diversity. 2006. Available online: http://ww2.bgbm.org/EuroPlusMed/ (accessed on 26 July 2018).

25. Dajic-Stevanovic, Z.; Pecinar, I.; Kresovic, M.; Vrbnicanin, S.; Tomovic, L. Biodiversity, Utilization and Management of Grasslands of Salt Affected Soils in Serbia. Community Ecol. 2008, 9, 107-114. [CrossRef]

26. Peeters, A.; Dajić, Z. Grassland Management Study for the Stara Planina, Mt. Nature Park. Proposals of Biodiversity Restoration Measures; Ministry of Agriculture, Forestry and Water Management of the Republic of Serbia (Project report): Knyzhevac, Serbia, 2006.

27. AS1064, Sampling Feed for Analysis; State University Fargo: Fargo, ND, USA, 2012.

28. AOAC. Official Methods of Analysis of AOAC International, 17th ed.; AOAC: Gaithersburg, MD, USA, 2000; (method number 991.20; 33.2.11).

29. ICAR (International Committee for Animal Recording). Guidelines for Dairy Cattle Milk Recording; ICAR: Roma, Italy, 2017.

30. IDF Standard 141C. Whole Milk. Determination of Milk Fat, Protein and Lactose Content-Guide for the Operation of Mid Infrared Instruments; International Dairy Federation: Brussels, Belgium, 2000.

31. ISO Standard 15885 (ISO-IDF, 2002). Milk Fat_Determination of the Fatty Acid Composition by Gas-Liquid Chromatography; International dairy federation: Brussels, Belgium, 2002.

32. Stat-Soft Inc. STATISTICA (Data Analyses Software System), v.10.0.2010, USA. 2010. Available online: http://www.statsoft.com (accessed on 3 August 2020).

33. Metera, E.; Sakowski, T.; Słoniewski, K.; Romanowicz, B. Grazing as a Tool to Maintain Biodiversity of Grassland-A Review. Anim. Sci. Papers Rep. 2010, 28, 315-334.

34. Radonjic, D.; Djordjevic, N.; Markovic, B.; Markovic, M.; Stesevic, D.; Dajic-Stevanovic, Z. Effect of Phenological Phase of Dry Grazing Pasture on Fatty Acid Composition of Cows' Milk. Chil. J. Agric. Res. 2019, 79, 278-287. [CrossRef]

35. Pulević, V. Građa za Vaskularnu Floru Crne Gore; Republički Zavod za Zaštitu prirode Crne Gore: Podgorica, Montenegro, 2005.

36. Pulević, V.; Bulić, Z. Bibliografija o Flori i Vegetacijicrne Gore; Republički Zavod za Zaštitu Prirode Crne Gore: Podgorica, Montenegro, 2004.

37. Pulević, V.; Bulić, Z. Bibliografija o flori i vegetaciji Crne Gore; Republički zavod za zaštitu prirode: Podgorica, Montenegro, 2012; Treća dopuna, Posebno izdanje; p. 150.

38. Blečić, V.; Lakušić, R. Prodromus Biljnih Zajednica Crne Gore. Glasnik Republičkog Zavoda za Zastitu Prirode i Prirodnjačkog Muzeja 1976, 9, 57-98.

39. Bešić, L. Flora i Vegetacija Bjelopavličke Ravnice u Crnoj Gori. Magistarski Rad; Sveučilište u Zagrebu: Zagreb, Croatia, 1978.

40. Hadžiablahović, S. The Diversity of the Flora and Vegetation of Lake Skadar/Shkodra. In The Skadar/Shkodra Lake Environment, Hdb Env Chem, Pešić, V., Karaman, G., Kostianoy, A.G., Eds.; Springer International Publishing AG: Cham, Switzerland, 2018. [CrossRef]

41. Petrović, D.; Hadžiablahović, S.; Vuksanović, S.; Mačić, V.; Lakušić, D.; Milanović, Đ. Katalog tipova staništa Crne Gore značajnih za EU u Crnoj Gori, verzija 3; Podgorica-Beograd-Banja Luka: Podgorica, Montenegro, 2019.

42. Almeida, J.P.F.; Rebello-Andrade, C.S.C.; Rodrigues, A.M. Feeding Value of Portuguese Mediterranean Annual-Type Rainfed Pastures. Grassl. Sci. Eur. 2017, 22, 94-97.

43. Duignan, L.; ÓhUallacháin, D.; Finn, J.A.; Browne, A.; McGurn, P.; Moran, J. The Agronomic and Biodiversity Value of Semi-Natural Grassland Types under Different Grazing Management. Grassl. Sci. Eur. 2018, 23, 160-163.

44. Botana, A.; Resch-Zafra, C.; Pereira-Crespo, S.; Veiga, M.; González, L.; Dagnac, T.; Lorenzana, R.; Fernández-Lorenzo, B.; Flores-Calvete, G. Contrasting Diets and Milk Composition on Galician Dairy Farms. Grassl. Sci. Eur. 2018, 23, 697-709.

45. Akert, F.; Reidy, B.; Kreuzer, M.; Berard, J. Coagulation Properties and Composition of Milk from Cows Fed Grass with Different Amounts of Concentrates. Grassl. Sci. Eur. 2017, 22, 91-94. 
46. Veiga, M.; Botana, A.; González, L.; Resch-Zafra, C.; Pereira-Crespo, S.; Lorenzana, R.; Dagnac, T.; Fernández-Lorenzo, B.; Plata-Reyes, D.A.; Flores-Calvete, G. Milk Yield and Milk Composition Characteristics of Grazing and All-Silage Dairy Systems. Grassl. Sci. Eur. 2018, 23, 784-786.

47. Gulati, A.; Galvin, N.; Lewis, E.; Hennessy, D.; O'Donovan, M.; McManus, J.J.; Fenelon, M.A.; Guinee, T.P. Outdoor Grazing of Dairy Cows on Pasture Versus Indoor Feeding on Total Mixed Ration: Effects on Gross Composition and Mineral Content Milk during Lactation. J. Dairy Sci. 2017, 101, 2710-2723. [CrossRef]

48. Shingfield, K.J.; Bonnet, M.; Scollan, N.D. Recent Developments in Altering the Fatty Acid Composition of Ruminant-Derived Foods. Animal 2013, 7, 132-162. [CrossRef]

49. Koczura, M.; Barmaz, A.; Pervier, S.; Kreuzer, M.; Bruckmaier, R.; Berard, J. Effect of Low Input Alpine Grazing Systems on Fatty Acid Profile and Coagulation Properties of Milk. Grassl. Sci. Eur. 2017, 22, 176-179.

50. Tsvetkova, V.; Angelov, L. Influence of Botanical Diversity in the Natural and Cultivated Pastures on the Lipid Content and Fatty Acid Composition of Grass in the Region of the Middle Rhodopes. Bulg. J. Agric. Sci. 2010, 19, 81-86.

51. Stergiadis, S.; Leifert, C.C.; Seal, J.; Eyre, M.D.; Larsen, M.K.; Slots, T.; Nielsen, J.H.; Butler, G. A Two-Year Study on Milk Quality from Three Pasture-Based Dairy Systems of Contrasting Production Intensities in Wales. J. Agric. Sci. 2015, 153, 708-731. [CrossRef]

52. Dias, K.M.; Gama, M.A.S.; Schmitt, D.; Sbrissia, A.F. Milk Fatty Acid Composition of Unsupplemented Dairy Cows Grazing on a Tropical Pasture. Rev. Bras. Zootec. 2019, 48, e20190088. [CrossRef]

53. Coppa, M.; Chassaing, C.; Ferlay, A.; Agabriel, C.; Laurent, C.; Borreani, G. Potential of Milk Fatty Acid Composition to Predict Diet Composition and Authenticate Feeding Systems and Altitude Origin of European Bulk Milk. J. Dairy Sci. 2015, 98, 1539-1551. [CrossRef] [PubMed]

54. Revello-Chion, A.; Tabacco, E.; Peiretti, P.G.; Borreani, G. Variation in the Fatty Acid Composition of Alpine Grassland during Spring and Summer. Agron. J. 2011, 103, 1072-1080. [CrossRef]

55. Glasser, F.; Doreau, M.; Maxin, G.; Baumont, R. Fat and Fatty Acid Content and Composition of Forages: A Meta-Analysis. Anim. Feed Sci. Technol. 2013, 185, 19-34. [CrossRef]

(C) 2020 by the authors. Licensee MDPI, Basel, Switzerland. This article is an open access article distributed under the terms and conditions of the Creative Commons Attribution (CC BY) license (http://creativecommons.org/licenses/by/4.0/). 